\title{
The partisan politics of the penal-welfare nexus: a quantitative analysis of party influence on the relationship between penal and welfare policies
}

\author{
Helge Staff ${ }^{1 * *}$ (D) and Georg Wenzelburger ${ }^{2}$ \\ ${ }^{1}$ Leibniz Center for Science and Society, Leibniz University Hannover, Germany and ${ }^{2}$ Faculty of Social \\ Sciences, University of Kaiserslautern, Germany \\ ${ }^{*}$ Corresponding author. E-mail: helge.staff@lcss.uni-hannover.de
}

(Received 29 July 2019; revised 04 June 2020; accepted 30 June 2020; first published online 03 August 2020)

\begin{abstract}
Evidence of a link between the retrenchment of the welfare state and the expansion of the penal state has sparked a debate about the existence of a nexus. In this study, we critically explore this link by focusing on political parties. First, we argue that welfare and penal policies are likely to follow distinct paths, with left-liberal/green parties pushing for less punitive penal and market-liberal/conservative parties for less generous welfare policy. Second, we only expect a nexus between both policy domains if conservative or "third way" social democratic governments are in power. The former follows a coherent ideology, the latter compensates for welfare retrenchment with tough-on-crime policies. We test these claims quantitatively on a unique dataset covering all changes to welfare and penal legislation in Denmark, Germany, the United Kingdom and France between 1990 and 2014 and find our expectations supported except conservative influence on the penal-welfare nexus.
\end{abstract}

Keywords: law and order; partisan effects; penal policies; welfare state

\section{Introduction}

Neoliberalism has been seen as one of the ideational driving forces for societal and political change in Western democracies (Crouch 2013) spurring a wide range of changes in different realms of politics and society (Centeno and Cohen 2012): a retreat of the interventionist state, visible by reduced taxation and privatisation (Zohlnhöfer et al. 2017); a shrinking welfare state, characterised by increased individual responsibility, less generous benefits and an emphasis on workfare (Simmons et al. 2006; Béland 2009; Ferrera 2013); and an increased penal state, characterised by a turn towards harsher punishment in Western liberal democracies (e.g. Garland 2001; Wacquant 2009b). Reaching beyond specific policy domains, some authors have even related economic neoliberalism with a growing penal state, treating (c) The Author(s), 2020. Published by Cambridge University Press. 
neoliberal ideology as general pressure that affects not only the economic and social realm, but also law and order policies:

[T] he state stridently reasserts its responsibility, potency, and efficiency in the narrow register of crime management at the very moment when it proclaims and organizes its own impotence on the economic front, thereby revitalizing the twin historical-cum-scholarly myths of the efficient police and the free market. (Wacquant 2009b: xviii)

A cross-national comparison of welfare generosity and penal policies seems to support this claim. Cavadino and Dignan have for instance famously shown that the rise of neoliberal ideology has led the Anglo-Saxon family of nations to resort to incarceration much more heavily than the rest of the Western world (Cavadino and Dignan 2006), and the Scandinavian countries in particular. Related observations of systematic cross-country differences have been made by Lacey (2008) emphasising differences in capitalist systems.

However, when it comes to the reasons for this pattern, the picture is complex. Some authors, drawing on the seminal 1939 study by Rusche and Kirchheimer (1968), discuss the two policy sectors as linked by discourse (Melossi 1987), as instruments to handle "social marginality" (Beckett and Bruce 2001) or to control labour surplus (Rodríguez-Menés and López-Riba 2019). Others hold that the nature of the capitalist system is responsible for the correlation between welfare generosity and penal policies (Lacey 2008; Lacey et al. 2018), while further studies have argued that welfare states affect individual's life chances and opportunity structures, e.g. through education and labour market security, resulting in different crime rates as well as penal policy reactions (Sutton 2010). However, the absence of politics and political parties in most of these accounts is striking. Evidently, power resources of classes and the respective political parties have been a powerful explanation of welfare state development (Korpi 1983; Esping-Andersen 1990; Korpi and Palme 2003) and political dynamics have also been discussed as affecting law and order and penal policies (Simon 2007; Wenzelburger 2015). However, the question whether political parties and competition between them affect the relationship of welfare and penal policies has been not studied, yet.

In this contribution, we show that political parties are key if we want to understand the apparent covariance between penal and welfare policies. In terms of theory, we argue that political parties matter in two respects. First, building on recent theories of party competition, which suggest that parties compete on both an economic left-right dimension and a cultural [Green-Alternative-Libertarian/ Traditional-Authoritarian-Nationalist (GALTAN)] dimension, we expect that parties hold distinct positions towards welfare state and penal issues. Whereas some parties, such as conservatives, will push for both penal harshness and welfare retrenchment, others, such as liberal parties, are critical of a big welfare state as well as of tough penal policies. Depending on government participation of these parties, this may result in contradicting trends in both policy domains. Second, we argue that some parties can be expected to actually relate penal and welfare policies in an ideologically coherent way. This is true not only for the obvious candidate conservative parties - but also for social democrats that embarked on a "third-way" 
policy platform. Building on the recent literature (Tham 2001; Wenzelburger and Staff 2017), we argue that third-way social democratic parties, which are electorally most vulnerable to welfare cutbacks, are likely to mix welfare cutbacks and harsher penal policies because they feel the need to show their voters that they still care about their security. They compensate, in a sense, the loss of social security with penal harshness - a strategy that speaks to broader sociological concepts of different means of social control. As our arguments largely draw on political and economic changes that have affected Europe from the 1980s onwards, both arguments are mainly applicable to this specific period and region.

In terms of empirics, we contribute a new dataset to the literature. It covers legislative changes in welfare and penal policies between the 1990s and 2014 in Denmark, Germany, the United Kingdom (UK) and France. The data enable us not only to test the actual legislative output - which is where partisan ideology should be most visible (Knill and Tosun 2012, 292) - but it also contains information on the time when a piece of legislation was enacted. We therefore can analyse whether penal legislation systematically follows welfare legislation. Our empirical analysis reveals that indeed, liberal parties push for less welfare and more liberal penal policies - a finding that shows that neoliberal ideology does not affect all parties and policy domains simultaneously. Second, we find that compensation effects are indeed visible for social democratic governments, but - surprisingly not for conservative parties. As our dataset starts in the mid-1990s when the third way was en vogue, this can be interpreted as a corroboration of the claim that social democrats that retrenched the welfare state resorted to tougher penal policies to signal their commitment to security by other means. ${ }^{1}$

The remainder of this article is structured as follows: in the next section, we discuss the existing theoretical and empirical literature on the penal-welfare nexus as well as literature on partisan effects, especially with regard to law and order policy. Based on this, we formulate our main hypotheses. The third section will then set out our methodological approach and explain the dataset before we will present the regression analyses in the fourth section. A discussion of the study's results in relation to the literature concludes the article.

\section{Theory}

\section{Parties and the penal-welfare nexus: a largely neglected field of study}

Empirically, comparative criminology has asserted in recent years that some connection seems to exist between the welfare state and the penal state. Most existing studies focus on cross-national differences and therefore emphasise variance in levels. In an important contribution, Cavadino and Dignan (2006) established a link between the level of punitiveness and the type of political economy drawing on Esping-Andersen's famous "worlds of welfare" typology (Esping-Andersen 1990) - with the less generous liberal welfare states being also more punitive than the more

\footnotetext{
${ }^{1}$ Besides, the results from our regression analyses also confirm the well-established relationship between the partisan composition of the government and welfare state policies, pointing to a strongly negative correlation between the participation of conservative parties and welfare state change (Allan and Scruggs Korpi and Palme 2003).
} 
generous social democratic ones, although exceptions exist. Embedding this idea into the broader concept of the varieties of capitalism (Hall and Soskice 2001), Lacey (2008) supports this finding and the general link between welfare provision and punitiveness with liberal market economies exhibiting higher punitiveness as coordinated market economies [see also Downes and Hansen (2006)]. Relying on a set of indicators instead of the imprisonment rate only, Wenzelburger (2018) confirms that countries group in distinct clusters reflecting their law and order policies as well as welfare state regimes [see also Norris (2009)]. Similarly, Lappi-Seppälä (2008) finds a link between welfare provision or de-commodification and imprisonment rates. Finally, while Tonry $(2007,17)$ acknowledges that greater income inequality is associated with higher imprisonment rates, he also points out that "distinctive national histories and cultural attitudes of individual countries" are most influential to explain national variations (Tonry 2015, 512).

While these studies reveal relevant patterns, comparing cross-national differences in penal and welfare policies is not a very precise test of the question of whether governments purposefully change penal and welfare policies in tune. In this respect, two different accounts have been put forward. The first explanation for such a penal-welfare nexus has been proposed by Wacquant (2009b), who argues that neoliberalism has to be understood as the common background for both welfare state retrenchment and penal harshness. The slightly different variations of his principal arguments converge on the view that inequality and poverty increase as a result of neoliberal economic and social policies (essentially, welfare retrenchment) to which governments then respond by toughening penal policies. The second explanation has been put forward by Sutton (2010) and (2013). He argues that the welfare state, or, more precisely, the labour market as well as education systems, structure opportunities of individuals over their life course and thereby affect their risk of committing a crime and, relatedly, aggregate rates of imprisonment. In this second explanation, inclusive labour markets and education systems favouring both employment and security lead to less crime and less punishment.

Although these studies advance our understanding of why welfare cutbacks may be accompanied by harsher penal policies, politics and political parties only play a minor role. While Wacquant seems to argue that neoliberalism affects all (in his cases, mostly the United States (US)) governments in a similar way (Wacquant 2001, 404), ${ }^{2}$ Sutton concedes that left-party power may actually be a root cause of the development of inclusive labour markets as well as "cross-class solutions to a wide range of social policy issues, including, apparently, less punitive responses to crime" (Sutton 2004, 185). Empirically, while not directly modelling the partisan influence on the penal-welfare nexus, he has repeatedly shown that left-party power - depending on the model specification - restricts mass incarceration (Sutton 2000, 2004, 2010, 2013). However, by focusing on a left-right divide (which may adequately represent the US party system), this work underestimates the multidimensionality of most other party systems in advanced democracies. The next section will, therefore, give a more complete account of how governmental policies are shaped by political parties and party competition.

${ }^{2}$ For a critique of his work, see Campbell (2010), Mayer (2010), Piven (2010), or Squires and Lea (2012). 


\section{Party competition on welfare and penal policies}

The theory of partisan politics explains policy outputs by analysing (1) which parties form the government and (2) by inspecting the ideological stance of these parties (Häusermann et al. 2013; Schmidt 1996). It is therefore crucial to understand how ideological differences of parties come about because they will affect policies once a party reaches office. According to standard theories of party competition (Sartori 1976; Stokes 1999; Adams et al. 2005), the ideological position of parties is formed in electoral competition for votes because parties' most important goal is to win elections, access to office, and, by this means, to influence policies in the interest of their constituency. However, the context in which this competition takes place varies substantially between countries: while the US party system is largely based on a single mainly economic dimension opposing Republicans and Democrats (Benoit and Laver 2006, 116), European party systems feature a greater number of parties, which exhibit distinct mixes of policy preferences along different policy dimensions. Especially from the 1990s onwards, most party systems in Western industrialised countries have developed two main dimensions of competition: an economic axis opposing parties of the left, that push for more state intervention in the economy and generous welfare states, to parties of the right, that hold a liberal view of free markets and individual responsibility; and a more and more important cultural axis (GALTAN) that opposes green/alternative/liberal (GAL) and traditional/authoritarian/nationalist (TAN) values, which are then represented in party competition by, for instance, green and liberal parties on the one and right-wing populist parties on the other hand (e.g. Kitschelt and Hellemans 1990; Kriesi et al. 2008; Kitschelt and Rehm 2016). If we adhere to this view, penal policies are an issue of the GALTAN axis as they touch positions towards authoritarian values and a more repressive public order (see also, Wenzelburger 2015).

This more adequate understanding of partisan competition has consequences for our theorising about whether welfare and penal policies are related. For welfare policies, the dynamics are quite straightforward. Based on Hibbs (1977) or Castles and McKinlay (1979), many studies confirmed the thesis that "parties matter" for welfare (Bradley et al. 2003; Korpi and Palme 2003; Allan and Scruggs 2004; Potrafke 2017) - although, following the findings by Pierson and others (Pierson 1994; Huber and Stephens 2001; Kittel and Obinger 2003), in a more nuanced way after the 1990s (Schmitt 2016; Jensen and Wenzelburger 2020b; Savage 2019). Hence, we expect that the standard left-right distinction holds for the partisan politics of the welfare state.

When it comes to penal policies, things get more complicated. Whereas European conservative parties, in general, favour free-market policies and advocate for a strong state in matters of security and crime (von Beyme 1982, 72-73), liberal parties in Europe have evolved as a defensive movement against the intrusions of monarchic states into the matters of its citizens. This applies to the relationship between market and state and explains the position of these parties on the economic axis, although left-liberal parties (such as the Dutch D66) are more open to state intervention than classic market-liberal ones (such as the Dutch VVD). Yet, it also applies to the GALTAN axis, where liberal parties also advocate limited state power over the individual citizen as institutionalised by civil rights (Smith 1988; 


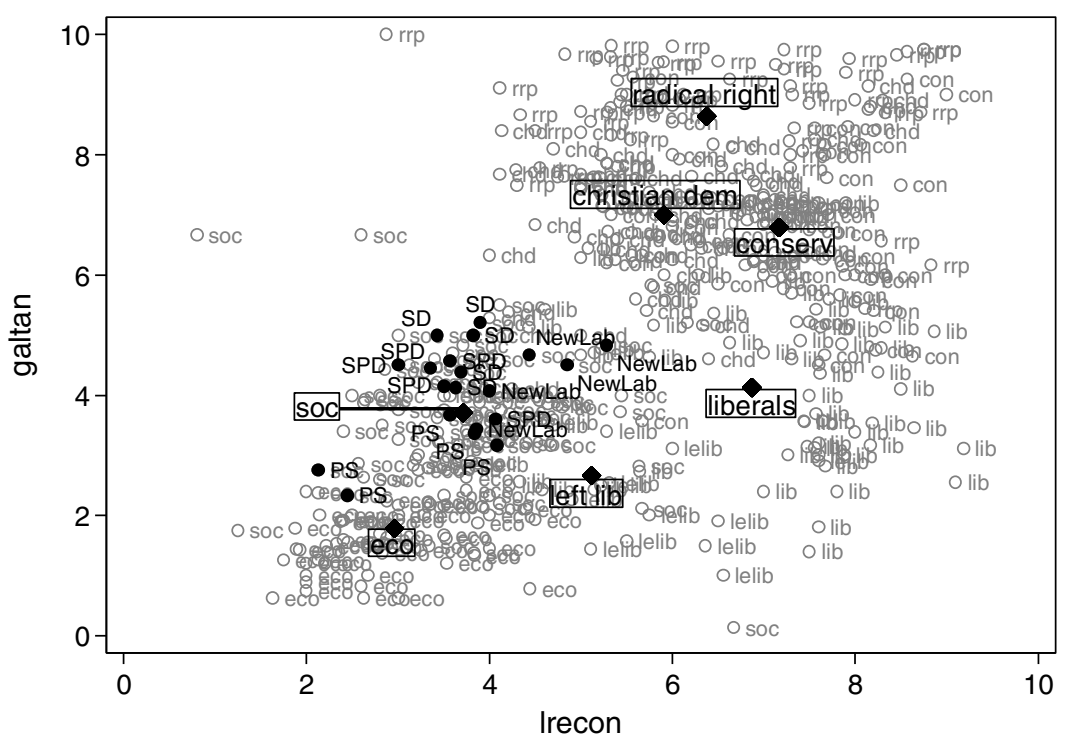

Figure 1. Party competition and the penal-welfare nexus.

Note: $y$-axis: (mean) position of the parties on the GALTAN-axis; $x$-axis: (mean) position of the parties on the economic left-right axis. All data are based on the positions estimated in the Chapel Hill expert survey (1999-2010) (Bakker et al. 2012); party labels: SD: cocial democrats (DEN); SPD: social democrats (Germany); PS: Socialist Party (France); NewLab: New Labour (UK). Party families: eco: ecologist/green parties; soc: social democratic parties.

von Beyme 1982, 47, 53). Green parties share the liberal stance on penal issues but are more pro-welfare (to different degrees, depending on the national context). Finally, the stance of Christian democratic and social democratic parties is more centrist. Christian democrats have been shown to favour a more repressive stance on penal policies while, at the same time, having a reputation of being clearly pro-welfare without supporting too universalistic programmes (Van Kersbergen and Manow 2009). And social democrats, while being the main advocates of state intervention and a strong welfare state, have developed over time a less distinct position in the realm of penal policies (e.g. on the GALTAN-axis). In fact, although traditionally following a rehabilitative ideal, European social democratic parties since the 1990s turned towards a much tougher policy position (Tham 2001; Estrada 2004; Newburn 2007; Wenzelburger and Staff 2017). They seem to struggle to cater to the traditional voter segment of the industrial worker with a more repressive stance while, at the same time, trying to garner the voter groups of sociocultural professionals, who clearly have a liberal view on penal policies (Kitschelt and Rehm 2016).

To substantiate this theoretical point empirically, we illustrate the positions of the major parties in 14 Western European countries (on the basis of the Chapel Hill expert survey ${ }^{3}$ [Bakker et al. 2012)] between 1999 and 2010 (Figure 1). In this figure, we have also plotted the mean values of the major party families (in purple).

\footnotetext{
${ }^{3}$ The Chapel Hill expert survey measures party position on a variety of issues based on evaluations by country experts.
} 
Given that party systems are dynamic and exposed to very country-specific features [e.g. the existence of regional parties (e.g. in Spain) or agrarian parties (e.g. in Scandinavia)], the data show a rather impressive coherence with our theoretical argument: in terms of economic policies, the "classic" left-right divide is clearly visible, whereas on the GALTAN dimension, liberal parties - and especially left-liberal ones - hold a more liberal position. Also, as expected, social democrats are more centrist on the GALTAN axis and more leftist on economic issues. On average, they hold almost the same position as market-liberals but are fairly more repressive than left-liberals. However, the average position for social democrats hides some substantial variation, as illustrated by the highlighted parties from our country sample: it is evident that those social democratic parties that have turned towards a more centrist course ("Third Way") are both more repressive on the GALTANdimension as well as more economically conservative. ${ }^{4}$

From this discussion, it follows that, in terms of European party politics, there is not much theoretical ground to expect a clear-cut left-right divide in terms of penal policies that follow the idea of left-wing leniency and right-wing repressiveness. Instead, we would expect that the position on the GALTAN-dimension matters most for penal policies whereas, for welfare policies, market liberals and conservatives should strive for smaller welfare states and social democrats adopting more generous social policies. ${ }^{5}$ The upshot of our argument can be condensed in the following hypotheses:

H1. (penal): The stronger the left-liberal or green parties are represented in a government, the less punitive is the government's penal policy.

H2. (welfare): The stronger the market-liberal and secular conservative parties are represented in a government, the less generous is the government's welfare policy.

\section{The partisan politics of the penal-welfare nexus}

As we have seen, party politics do not necessarily imply that penal and welfare policies move in parallel. However, while the separate theories of penal and welfare policies help us to understand how political parties affect the trajectories of legislation in both domains, it does not tell us much about the theorised nexus of both. To recall, the idea of a penal-welfare nexus considers both policies as different ways of social control. Consequently, in the era of neoliberalism when welfare policies are under pressure and retrenchment becomes the name of the game, an increasing reliance on penal harshness as a means of social control is the result. In other words, we have to ask which party family may be more or less inclined to actually link welfare and penal policies when in office, that is to adopt penal legislation in direct connection with welfare legislation.

\footnotetext{
${ }^{4}$ The two social-democratic outliers with rather repressive positions are from two small parties from Greece (Dikki 2006 and KKE in 2002). These positions can probably be explained by the specificities of party competition in this country.

${ }^{5}$ In fact, for a related policy realm - moral policies - such an effect by liberal parties has already been discovered (Budde et al. 2018).
} 
The case of liberal parties illustrates that this reasoning is very different from $\mathrm{H} 1$ and H2. According to our theoretical expectation above, liberal parties should push for less repressive penal and less generous social policies. However, while this expectation makes sense for both policy domains separately, it is difficult to come up with a theoretical argument why liberals should actually link both policy domains, why they should, for instance, accompany welfare cutbacks with more lenient penal policies.

This is different for both conservative and social democratic parties. Following our expectation above, conservatives ideologically prefer more repressive penal policies and a less expansive welfare state - an expectation well supported by the empirical literature (e.g. Roché 2012). Theoretically, following the criminological literature, it has also been shown that these parties link both welfare cuts and penal harshness in an overall neoliberal ideological discourse about punishment and welfare (Wacquant 2009a). To secure electoral support by their constituents in the middle and upper classes fearing social unrest and disorder following welfare retrenchments, conservative parties reaffirm the authority of the state via tougher penal policy (Wacquant 2009b, 7; 128-129). The ongoing capacity of the state to act and authorise its authority, despite an ideologically motivated welfare retrenchment, is (symbolically) proven by draconian sentencing and police presence. Quite straightforwardly then, we can expect that conservative parties should opt for a strategy, that relates a tough-on-crime stance and a rollback of the welfare state in an overarching strategy.

H3. (penal-welfare nexus): The strength of conservative parties in government will condition the penal-welfare nexus: if conservative parties dominate the government, welfare state cutbacks will be followed by more repressive penal policies.

More interestingly, however, the other party family for which such a link can be theorised are social democrats that governed in a context of "permanent austerity" (Pierson 2001). This expectation rests on two related arguments: ideology and vote-seeking. In terms of ideology, many social democratic governments endorsed the ideas of the third way, combining supply-side economics with welfare state reforms directed at activation and more precise targeting of benefits to certain groups (e.g. Clasen 2002; Huo 2009; Arndt 2013). The ideological basis was influenced by social theorist Anthony Giddens who argued that "inequality can no longer, if it ever could, be countered only by income transfers from the more to the less affluent" (Giddens 2000, 53). Instead, he recommended a more universal approach to inequality, which includes policies that were usually owned by the right, such as fighting crime and family breakdown (on Spain, see e.g. Medina-Ariza 2006). Hence, the ideological foundations of the third way actually linked up welfare and penal policies forming a common approach: supply-side economic policies, welfare state reform, and "tough on crime, tough on the causes of crime" were two sides of the same coin, an actual penal-welfare nexus. Older British approaches in critical criminology even point out a general link between the welfare and penal policy stance of (British) social democracy: "Hence, punishment for repentance is the social democratic second-line of social defence: it is the proclamation of the general interest against sectarian or individual recalcitrance. Thieves and hooligans 
harm not only the conduct of a conforming social life, but threaten also the meaningfulness - and hence the existence - of welfare programmes" (Taylor et al. 1975, 13).

From a vote-seeking perspective, linking penal and welfare policies also made sense. First of all, working-class voters live in those areas which suffer most from crime - and social-democratic leaders, such as Tony Blair, were well aware of this. "Labour people, certainly our voters, were really anxious about law and order issues and far more likely to be tough than soft," he writes in his memoirs, because usually the liberal middle-class "weren't the victims, but the poorer people - the very ones we said we represented - were" (Blair 2010, 55). Given that social democrats could no longer attract working-class citizens with the promise to expand the welfare state - due to the economic context - promising and implementing tough-on-crime policies was actually an intelligent electoral strategy to appeal to the working class (Drinkwater and Jennings 2017) [for a related argument, see also Stenson and Edwards (2001)]. The Swedish criminologist Henrik Tham (2001, 417) contrasts this with other political parties: "Conservative and Liberal parties have a tradition of favouring the slogan "He rules best who rules least." For Social Democrats, the very basis of their political platform is the idea that society can and should be improved for political reform. In a situation where representatives of an activist political party are restrained by the economy, the temptation to demonstrate indignation and to expand politics in the area of morality and symbolic action must be quite compelling." Reflecting these arguments on the third-way social democracy, we therefore formulate the following hypothesis:

H4. (penal-welfare nexus): The strength of third-way social democratic parties in government will condition the penal-welfare nexus: if third-way social democracy dominates the government, welfare state cutbacks will be followed by more repressive penal policies.

While the hypotheses follow straightforwardly from the theoretical model, two remarks are in order. First, concerning causal order, it should be emphasised that we expect penal policy changes to be reactions to welfare cutbacks, i.e. that they follow after welfare state retrenchment has been implemented. There are at least two reasons for assuming this direction of causality relating to the policy process and to electoral competition. In terms of policy-making, given that governments can hardly prepare and adopt several big reforms at the same time (Jones and Baumgartner 2005) and welfare state reforms are more pressing in times of fiscal constraint, it is conceivable that governments focus on social policy change first and compensate via penal policies in the second step, only if they succeed in adopting cutbacks. In addition, considering the dynamics of electoral competition, social policies should be more important to governments than penal policies, because they dominate the public agenda (Green-Pedersen 2019, 66; Svallfors 2012), particularly so in Western Europe. Therefore, our theorised link of compensation should be most relevant in situations in which governments cut welfare (and then compensate via tougher penal policies). Admittedly, Rusche and Kirchheimer (1968) argue that the penal-welfare nexus can be explained by the more cost-efficient control of labour surplus via repressive penal policy, which may 
suggest that welfare cutbacks come first. Yet, this classic argument about a linking mechanism may have lost some force in modern Europe as the cost of housing a single prisoner, e.g. in Germany, exceeds unemployment benefits by roughly $30,000 €$ per year (IAB 2017, 4; JM NRW 2018). In addition, our argument is chiefly about welfare policy change - and not unemployment (which we control for in our analyses below). Hence, while it seems difficult to come up with a theoretical argument according to which the welfare state is cut as a reaction to penal harshness, there are good theoretical reasons to expect the causal order as hypothesised above namely that penal policy changes follow changes to welfare legislation.

Second, it is important to emphasise that the theoretical framework is based on the dynamics that have been visible in European party systems during the last 20 years or so. Two-party systems as in the US have different characteristics, although, even there, the significance of the GALTAN-dimension of party competition is increasing. Finally, party competition in societies in Europe after 1989 is largely different from the situation in the postwar period (and even before), where the traditional economic cleavage has been much more important (Inglehart 2008; Kriesi et al. 2008). What we propose here is a model for European party systems after 1989 - a model that might not travel well to countries with other party system characteristics and to other periods of time.

\section{Methods and data}

\section{Data on welfare and penal legislation}

Our analysis is based on legislative events in four countries - Denmark, Germany, the UK and France - between 1990 and 2014. As the measurement of legislative events involved a manual coding of changes to penal and welfare legislation, an analysis covering a large number of countries was beyond the scope of this research. The selection of four European political systems follows directly the advice by King et al. (1994, 140-141), who suggest sampling on independent variables in order to achieve a heterogeneous sample, if an intentional selection of observations is needed. The political systems of Denmark, Germany, the UK and France do not only differ systematically in terms of Lijphart's (2012, 305-306) executives-parties and federal-unitary dimensions but also in terms of policy sector-related variables, such as crime rates, prison population and size of police forces (Eurostat). Moreover, the structure of the political economy and the welfare state differs between the four countries: our selection covers all three "worlds of welfare capitalism" (Esping-Andersen 1990) as well as the different varieties of capitalism (Hall and Soskice 2001; Thelen 2014). This is important as both, welfare regimes and the structure of the capitalist economy, have been argued to influence penal policies (Cavadino and Dignan 2006; Lacey 2008; Wenzelburger 2018). Hence, the four countries selected cover much variance on the side of explanatory variables as well as a major part of the European population and economy making them "substantively important cases" (Goertz and Mahoney 2012, 184-185).

In order to test our hypotheses, we run multiple regression analyses on a unique dataset that combines information on individual legislative events in the realm of penal and welfare policies that change the legislative status quo. For legislation on 


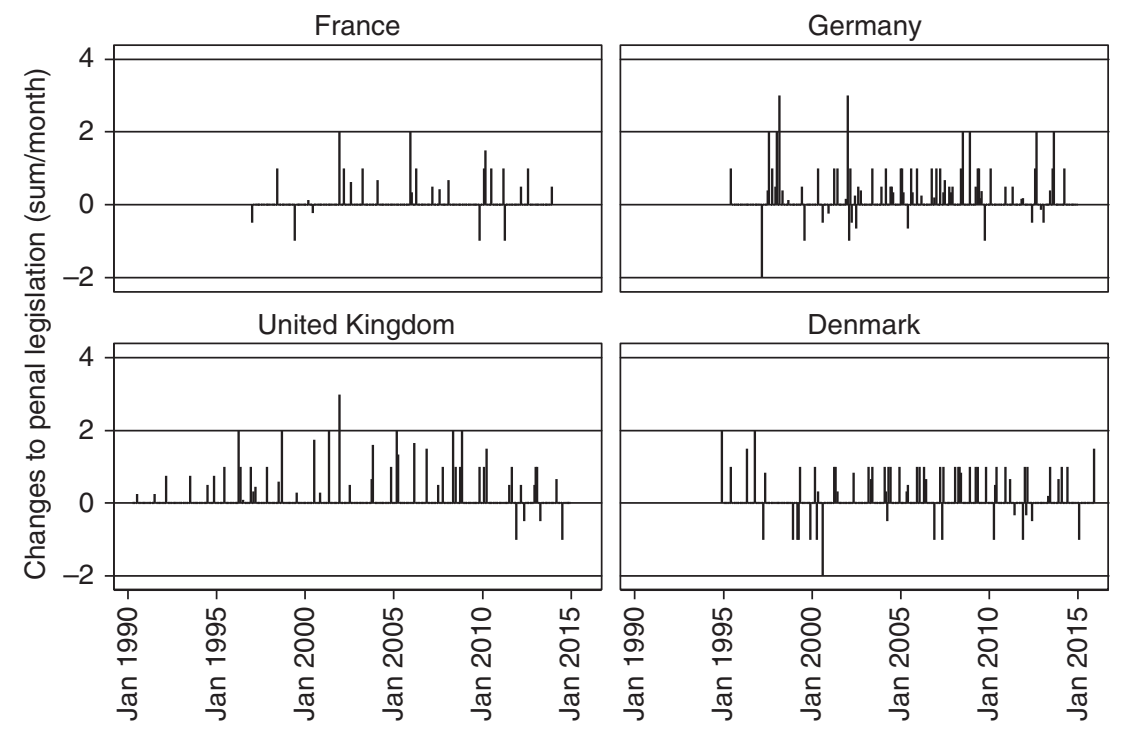

Figure 2. Changes to penal legislation in four countries. Note: Own data collection.

welfare policies, we use the WSRD (Jensen and Wenzelburger 2020b). The dataset of the project is based on individual changes to welfare state legislation in five European countries (Britain, Denmark, Finland, France and Germany) between the 1970s and today and contains information about what individual policy instruments (e.g. changes to the benefit duration and the benefit level of the qualification criteria) have been changed and coding of the direction of the change (cutback, expansion, or status quo) [for a discussion of the coding, see Lee et al. (2020)]. Legislative changes to penal policies have been coded by the authors. The coding involves a measure that indicates in what direction a piece of penal policy legislation has changed the status quo, ranging from -3 (strongly liberalising) to +3 (strongly repressive) (Wenzelburger and Staff 2016, 2017; Wenzelburger 2020). The values of -3 to +3 are assigned depending on the breadth (how many people are affected by a change?) and the depth of the legislative proposal (how strongly are civil liberties restricted?) (for a more thorough discussion of the coding scheme, see Wenzelburger and Staff 2016).

Figure 2 provides an overview of the coded legislative changes in penal policies aggregated as a sum of individual months in the four countries. ${ }^{6}$ Several observations stand out. First, it is clear from the graph that legislative activity was more intense in Germany, the UK and Denmark than in France - a finding that confirms the literature on legislative activity (Brouard et al. 2009). Second, the graph illustrates the more repressive legislative stance in Britain compared to Germany and Denmark (but also to France). This is mostly due to the high legislative activity

\footnotetext{
${ }^{6}$ Please note that the monthly sum is used here for illustrative purposes only. In the regression analyses, we use each legislative change as a unit observation (see Methods, dependent and independent variables).
} 
under the three government mandates of Prime Minister Tony Blair from 1997 to 2005 - and very much in line with qualitative literature (Newburn and Reiner 2007; Wenzelburger and Staff 2017). Third, the French pattern points to a distinctive period of harsher penal policy-making, which starts in 2002 and lasts until 2008 or so. Again, this reflects well with what we know from qualitative studies on penal policies in France and the shift towards tougher policies during the Presidencies of Jacques Chirac (2002-2007) and Nicolas Sarkozy (2007-2012) (Mucchielli 2010; Bourgoin 2015).

When it comes to welfare policies, the first impression is quite different: all countries have seen cutbacks and expansions - but to different degrees. In Germany, for instance, the budget consolidation packages of the last Kohl government in the mid-1990s are clearly visible, and so are the Hartz reforms in the mid-2000s adopted by the "red-green" coalition headed by Chancellor Schröder [for a more thorough review of German legislation, see Wenzelburger et al. (2018)]. Similarly, the British retrenchment in the mid-1990s is also discernible, and so is the slightly expansionist stance under New Labour in the 2000s - a picture that fits well with the qualitative evidence (Clasen 2005). In France, finally, one can observe a clear cutback-expansion-cutback pattern that corresponds to the rather austere policies under the Balladur and Juppé governments in the 1990s, followed by an expansionist stance of the left-wing government by Jospin, and, again, a more retrenchment-oriented stance under the Prime Ministers Raffarin, de Villepin and Fillon from 2002 onwards [for qualitative evidence, see Elbaum (2011), Palier (2005)]. Finally, most changes have been coded in Denmark with three big labour market reform packages introduced in 1993, 1995 and 1998 standing out as particularly voluminous instances of welfare retrenchment (Arndt 2013, 132-137). Finally, it is also visible that the extent of legislative changes varies between countries. This is why we include country dummies in the regression analyses to account for these idiosyncrasies (this is similar to estimating fixed effects regression).

\section{Methods, dependent and independent variables}

Our regression analysis comes in two steps. In the first step, we test penal and welfare legislation individually using the partisanship variables as main independent variables and combining them with a standard set of covariates that have been shown to be influential in state-of-the-art quantitative studies of penal (Sutton 2004; Wenzelburger 2015) and welfare policies (Allan and Scruggs 2004; Schmitt 2016). As discussed above, the dependent variables in these regressions are individual changes to the legislative status quo $(n=743$ for the welfare dataset and $n=880$ for the penal policy dataset). Both dependent variables are ordinal scaled, running from -1 to 1 in the case of welfare state legislation, and from -2 to 3 in the case of penal legislation. Concerning independent variables, we control for the fiscal and economic context in both instances (growth, unemployment and public debt), including violent crime (homicide) and fear of crime to the penal policy regressions and union density and the openness of the economy for welfare policies. These covariates belong to the standard indicators used in quantitative studies on the respective policies. 
Partisan effects are tested via an indicator that calculates the share of cabinet seats held by the respective party family, as we are primarily interested in the question whether it matters for policy change that a certain party is part of the government (or not) (for summary statistics, see Table A1, Appendix). We differentiate between the main party families in which we are interested, that is conservatives, social democrats, greens and liberal parties (see Table 1). Moreover, in Denmark and France where left-liberal parties exist, we distinguish between left liberals and market liberals. German and British liberals are coded as market liberals given that this strand dominated the two parties during our observation period. We also include a dummy measuring for the only social democratic government that has been largely immune to the ideas of the third way, which is the French government of Jospin from 1997 to 2002 (Clift 2000; Bell 2003). ${ }^{7}$

For both regressions, we use ordinal logistic regression and run a linear ordinary least squares (OLS) model as a robustness check, given that our units of analysis are individual legislative changes and therefore ordinal scaled. For both regressions, we focus on similar time periods $(1990-2014)^{8}$. Besides, we include country dummies to account for unit-specific heterogeneity and estimate robust standard errors (Huber-White sandwich estimator) to account for misspecification in the data. Country dummies are particularly relevant because the extent of legislative activity seems to follow country-specific patterns (see Figures 2 and 3).

In order to test $\mathrm{H} 3$ and $\mathrm{H} 4$, we build - in the second step - a dataset that combines both the welfare state change in the six months preceding a legislative change of penal policies as an independent variable and, as a dependent variable, the size of penal policy change. We use a lag of six months here not only to avoid endogeneity - penal policies in year $t$ can hardly affect welfare policy in years $t-7$ to $t-1$ - but also, because our hypothesised theoretical link of penal policy change compensating for welfare cutbacks suggests that penal policy change is a reaction to welfare cutbacks and not the other way around - which implies a time lag. Taking an average of six months before the implementation of a penal policy change seems reasonable given the length of a legislative process. ${ }^{9}$

\section{Empirical analyses}

The empirical investigation of the penal-welfare nexus is structured in two steps. In the following paragraphs, we first analyse whether the participation of marketliberal and conservative parties is significantly related to welfare state retrenchment. This comes down to testing H2. In the second, step, we estimate regressions to predict penal policy change. Here, we are chiefly interested in the effect of left-liberal and green parties (H1) as well as whether a nexus between penal and welfare policies is visible in the data under the condition that conservative (H3) and third-way social democratic

\footnotetext{
${ }^{7}$ In fact, some commentators have argued that was only the government under President François Hollande (2012-2017) which embarked, with a substantial time lag, on a third-way policy agenda (Lohrenz 2014).

${ }^{8}$ For France, Denmark, and Germany, the data on penal legislation start in the mid-1990s, though.

${ }^{9} \mathrm{We}$ have also used the average change of welfare legislation in the 12 months before a change to penal policies was implemented. Results do not change substantially, though.
} 
Table 1. Coding of party families and their participation in cabinet (in brackets)

\begin{tabular}{|c|c|c|c|c|c|}
\hline & \multirow[b]{2}{*}{ Conservatives } & \multicolumn{2}{|c|}{ Liberals } & \multirow[b]{2}{*}{ Social democrats } & \multirow[b]{2}{*}{ Greens } \\
\hline & & Market liberals & Left liberals & & \\
\hline DEN 1994-2014 & KF (2001-2011) & Venstre (2001-2011) & $\begin{array}{c}\text { Radikale Venstre } \\
\quad(2011-2015)\end{array}$ & SD (1994-2001, 2011-2015) & \\
\hline FRA 1997-2014 & UMP (2002-2012) & UDF/NC (2002-2012) & $\begin{array}{c}\text { PRG }(1997-2002 \\
2012-2017)\end{array}$ & PS (1997-2002, 2012-2017) & $\begin{array}{l}\text { Verts, Europe Écologie } \\
\quad(2012-2014)\end{array}$ \\
\hline GER 1995-2014 & - & \multicolumn{2}{|c|}{ FDP $(1994-1998,2009-2014)$} & SPD (1998-2009; 2014) & B90/Grüne (1998-2005) \\
\hline UK 1990-2014 & $\begin{array}{l}\text { Conservatives } \\
(1990-1997,2010)\end{array}$ & \multicolumn{2}{|c|}{ Liberal Democrats (2010-2015) } & Labour (1997-2010) & \\
\hline
\end{tabular}

Note: We only report the coding for the time period covered in our analysis (see first column). 
France

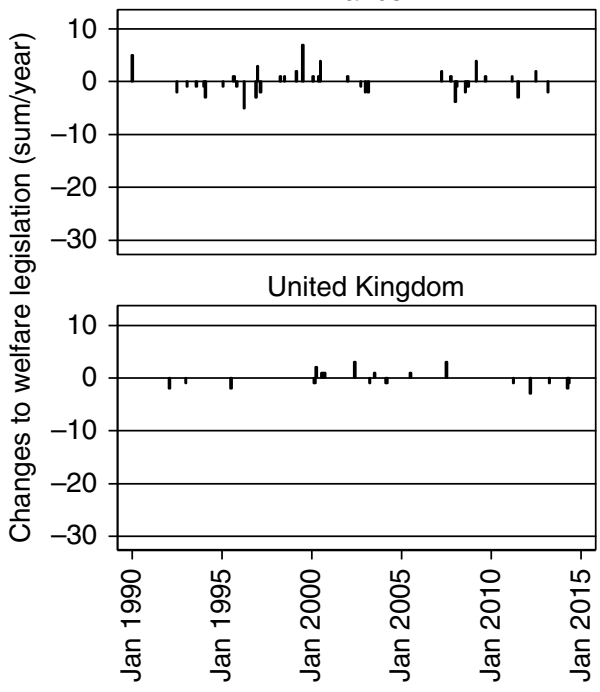

Germany

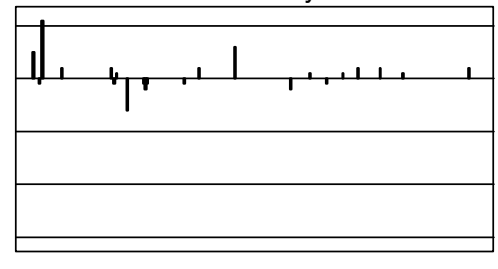

Denmark

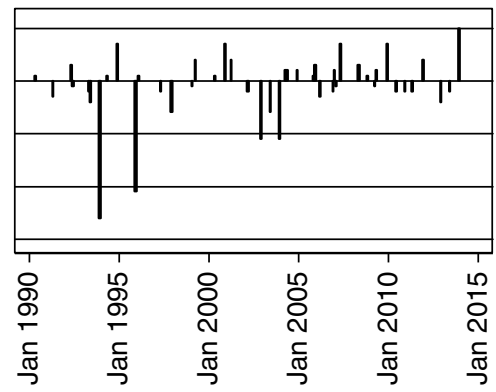

Figure 3. Changes to welfare legislation in four countries. Note: Data collected by WSCEP (Jensen et al. 2018).

(H4) parties are strongly represented in government. We always present models in which we include the indicators of partisan strength in the cabinet (share of cabinet seats of the respective party) and the full set of covariates distilled from the literature first. We then go on and present parsimonious models to see whether our results hold if we exclude nonsignificant variables.

Table 2 reports the results for the empirical associations between the cabinet share of different party families and welfare legislation. Our main independent variables (in $\mathrm{H} 2$ ) are the cabinet shares of conservative and market-liberal parties. We also include social democratic parties in separate estimations, as they are highly correlated with (the absence of) conservative parties in government. The results of all models are clear-cut: a higher share of conservative parties in government is associated with more pronounced welfare cutbacks. This confirms H2. The same seems to be true for market-liberal parties, too, but the lower significance (and the absence of it in the linear models) shows that this effect needs to be taken with a grain of salt. In contrast, strong government participation of social democrats increases the chances of welfare state expansions. The results for left-liberal and green parties do not point to relevant associations. ${ }^{10}$ In terms of substance, Figure 4 illustrates the results for $\mathrm{H} 2$. Based on predictive margins, an increase

\footnotetext{
${ }^{10}$ The negative coefficient for cabinet seat shares of green parties while controlling for social democratic governments is due to a suppressor effect, as social democrats and greens have often governed together in the countries under review here, and the effect of social democrats seems to outweigh the effect of greens, here. Together with the results in models 1,3 , and 5 , it seems reasonable to interpret this as an overall nonsignificant effect of government participation of green parties on welfare legislation.
} 
Table 2. Political parties' impact on welfare legislation

\begin{tabular}{|c|c|c|c|c|c|c|}
\hline & (1) & (2) & (3) & (4) & (5) & (6) \\
\hline & ologit, full & $\begin{array}{l}\text { ologit, } \\
\text { full }\end{array}$ & $\begin{array}{l}\text { ologit, } \\
\text { parsim }\end{array}$ & $\begin{array}{l}\text { ologit, } \\
\text { parsim }\end{array}$ & ols, parsim & ols, parsim \\
\hline \multirow[t]{2}{*}{ Cab seats conservatives } & $-0.0090^{\star *}$ & & $-0.012^{\star \star \star}$ & & $-0.0055^{\star \star \star}$ & \\
\hline & $(-2.10)$ & & $(-3.27)$ & & $(-3.52)$ & \\
\hline \multirow{2}{*}{$\begin{array}{l}\text { Cab seats market } \\
\text { liberals }\end{array}$} & $-0.013^{\star}$ & & $-0.013^{\star}$ & & -0.0046 & \\
\hline & $(-1.68)$ & & $(-1.72)$ & & $(-1.47)$ & \\
\hline \multirow{2}{*}{$\begin{array}{l}\text { Cab seats social } \\
\text { democrats }\end{array}$} & & $0.012^{\star \star}$ & & $0.014^{\star \star \star}$ & & $0.0060^{\star \star *}$ \\
\hline & & $(2.56)$ & & $(3.68)$ & & $(3.91)$ \\
\hline \multirow[t]{2}{*}{ Cab seats left liberals } & -0.021 & -0.011 & -0.034 & -0.023 & -0.013 & -0.0089 \\
\hline & $(-0.80)$ & $(-0.52)$ & $(-1.38)$ & $(-1.22)$ & $(-1.20)$ & $(-1.13)$ \\
\hline \multirow[t]{2}{*}{ Cab seats greens } & -0.022 & $-0.046^{\star \star}$ & -0.016 & $-0.049^{\star \star \star}$ & -0.0063 & $-0.021^{\star \star \star}$ \\
\hline & $(-1.42)$ & $(-2.38)$ & $(-1.15)$ & $(-2.73)$ & $(-0.98)$ & $(-2.77)$ \\
\hline \multirow{2}{*}{$\begin{array}{l}\text { Economic growth } \\
\text { (prev. quarter) }\end{array}$} & $0.10^{\star \star}$ & $0.11^{\star \star \star}$ & $0.078^{\star \star}$ & $0.092^{\star \star}$ & $0.040^{\star \star}$ & $0.046^{\star \star *}$ \\
\hline & $(2.43)$ & $(2.66)$ & $(2.06)$ & $(2.46)$ & $(2.23)$ & $(2.62)$ \\
\hline \multirow[t]{2}{*}{ Fiscal balance (lag) } & $0.19^{\star \star \star}$ & $0.18^{\star \star \star}$ & $0.19^{\star \star \star}$ & $0.18^{\star \star \star}$ & $0.083^{\star \star \star}$ & $0.077^{\star \star \star}$ \\
\hline & $(4.34)$ & $(4.17)$ & $(5.28)$ & $(4.86)$ & $(5.67)$ & $(5.17)$ \\
\hline \multirow{2}{*}{$\begin{array}{l}\text { Unemployment } \\
\text { (preced. six months) }\end{array}$} & -0.044 & -0.047 & & & & \\
\hline & $(-0.78)$ & $(-0.84)$ & & & & \\
\hline \multirow[t]{2}{*}{ Union density } & -0.086 & -0.077 & & & & \\
\hline & $(-1.48)$ & $(-1.36)$ & & & & \\
\hline \multirow[t]{2}{*}{ Openness of economy } & -0.018 & -0.019 & & & & \\
\hline & $(-1.02)$ & $(-1.15)$ & & & & \\
\hline \multirow[t]{2}{*}{ Constant (ols) } & & & & & 0.36 & -0.16 \\
\hline & & & & & $(1.47)$ & $(-1.42)$ \\
\hline \multirow[t]{2}{*}{ Constant (ologit, cut1) } & -8.94 & -7.32 & $-1.12^{\star}$ & 0.15 & & \\
\hline & $(-1.60)$ & $(-1.33)$ & $(-1.94)$ & $(0.58)$ & & \\
\hline \multirow[t]{2}{*}{ Constant (ologit, cut2) } & -8.57 & -6.95 & -0.76 & $0.51^{\star}$ & & \\
\hline & $(-1.54)$ & $(-1.27)$ & $(-1.33)$ & $(1.94)$ & & \\
\hline$n$ & 701 & 701 & 733 & 733 & 733 & 733 \\
\hline Pseudo $R^{2 /} R^{2}$ & 0.056 & 0.057 & 0.058 & 0.099 & 0.099 & 0.101 \\
\hline
\end{tabular}

Note: Country dummies included; ${ }^{*} \mathrm{p}<0.1$, ${ }^{\star *} \mathrm{p}<0.05$, ${ }^{\star \star \star} \mathrm{p}<0.01$.

in the conservative cabinet seat share from $0 \%$ to $50 \%$ raises the probability of a cutback from around $45 \%$ to $55 \%$ and over $65 \%$ for an entirely conservative cabinet (e.g. in Britain 1990-1997).

From the covariates included in the model, only economic growth and fiscal balance seem to affect the probability of welfare state change significantly. The direction is as expected: high growth and a positive fiscal balance increase the chances for expansions: the better the economic prospects, the more money 


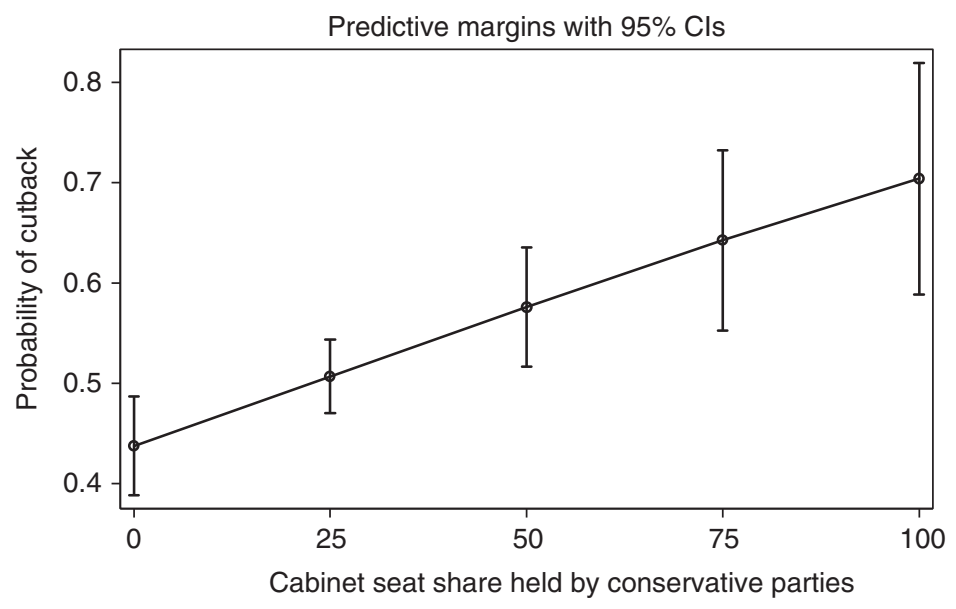

Figure 4. Marginal effect - probabilities of cutback and conservative parties.

is there to spend on welfare. In sum, the results as reported in Table 2 are a solid corroboration of the "old politics" thesis, according to which social democratic parties still affect welfare legislation in a positive sense, even in times of permanent austerity - although the relationship might have been even stronger in the decades before (Jensen and Wenzelburger 2020a).

Table $3^{11}$ presents the results for penal legislation to test the direct influence of left-liberal parties on penal policies (H1) as well as the theorised conditional influence of conservative (H3) and third-way social democratic parties (H4) on the nexus of welfare and penal policies. We report estimations of both ordinal logit regressions and, for the ease of interpretation, linear OLS - but the results are similar. As for welfare legislation, we present full models in which we have included the cabinet seat shares of the relevant parties and covariates (models 1-3), as well as more parsimonious models (4-8) in which we omit clearly nonsignificant variables. Again, conservatives/market liberals and social democrats are not included simultaneously due to high correlation. The same is true for three of our covariates, namely fear of crime, homicide, and the migration rate, which is why we do not include them together in the models. Furthermore, we include two interactions reflecting $\mathrm{H} 3$ and $\mathrm{H} 4$ in models 9 and 10. Additional interactions for other parties are included in the Appendix (Table A2).

Several observations can be made from Table 3. First of all, supporting H1, the regression estimates indicate a negative relationship between the presence of left-liberal parties and less repressive penal legislation. The effect is substantial for left-liberals but also visible for market liberals. The same is true for green parties, although the results are less robust here. Interestingly, although not hypothesised directly, social democrats seem to be more repressive than conservatives during

\footnotetext{
${ }^{11}$ Please note that the sample as well as the dependent variable in Tables 2 and 3 differ. The dependent variable in welfare legislation (Table 2) runs from -1 to +1 , whereas it runs from -2 to +3 for penal policy (Table 3). Therefore, coefficients cannot be compared across tables.
} 
Table 3. Political parties' impact on penal legislation

\begin{tabular}{|c|c|c|c|c|c|c|c|c|c|c|}
\hline & (1) & (2) & (3) & (4) & (5) & (6) & (7) & (8) & (9) & (10) \\
\hline & ologit, full & ologit, full & ologit, full & $\begin{array}{l}\text { ologit, } \\
\text { parsim }\end{array}$ & $\begin{array}{l}\text { ologit, } \\
\text { parsim }\end{array}$ & $\begin{array}{l}\text { ologit, } \\
\text { parsim }\end{array}$ & ols (mod4) & ols (mod6) & $\begin{array}{c}\text { ols } \\
\text { (interac) }\end{array}$ & $\begin{array}{c}\text { ols } \\
\text { (interac) }\end{array}$ \\
\hline \multirow{2}{*}{$\begin{array}{l}\text { Average welfare change } \\
\text { prec. } 6 \mathrm{~m}\end{array}$} & 0.0012 & 0.017 & 0.017 & 0.014 & 0.020 & 0.021 & 0.0044 & 0.0080 & -0.00062 & $0.038^{\star \star}$ \\
\hline & $(0.05)$ & $(0.67)$ & $(0.66)$ & $(0.57)$ & $(0.78)$ & $(0.85)$ & $(0.45)$ & $(0.85)$ & $(-0.06)$ & (2.42) \\
\hline \multirow[t]{2}{*}{ Cab seats conservatives } & $-0.0075^{\star *}$ & $-0.0084^{\star \star \star}$ & & $-0.0083^{\star \star \star}$ & & & $-0.0040^{\star \star \star}$ & & $-0.0037^{\star \star *}$ & \\
\hline & $(-2.48)$ & $(-3.10)$ & & $(-3.07)$ & & & $(-3.64)$ & & $(-3.37)$ & \\
\hline \multirow{2}{*}{$\begin{array}{c}\text { Welfare change } \\
\text { Conservatives }\end{array}$} & & & & & & & & & 0.00030 & \\
\hline & & & & & & & & & $(1.09)$ & \\
\hline \multirow[t]{2}{*}{ Cab seats market liberals } & $-0.019^{\star \star}$ & $-0.020^{\star *}$ & & $-0.021^{\star \star \star}$ & & & $-0.0088^{\star \star \star}$ & & $-0.0090^{\star \star \star}$ & \\
\hline & $(-2.43)$ & $(-2.56)$ & & $(-2.89)$ & & & $(-3.39)$ & & $(-3.42)$ & \\
\hline \multirow[t]{2}{*}{ Cab seats left liberals } & $-0.087^{\star \star \star}$ & $-0.091^{\star \star \star}$ & $-0.052^{\star \star \star}$ & $-0.092^{\star \star \star}$ & $-0.042^{\star \star \star}$ & $-0.038^{\star \star \star}$ & $-0.038^{\star \star \star}$ & $-0.016^{\star \star \star}$ & $-0.038^{\star \star \star}$ & $-0.017^{\star \star \star}$ \\
\hline & $(-3.63)$ & $(-3.87)$ & $(-3.21)$ & $(-3.94)$ & $(-2.61)$ & $(-2.61)$ & $(-4.38)$ & $(-2.89)$ & $(-4.38)$ & $(-2.98)$ \\
\hline \multirow[t]{2}{*}{ Cab seats greens } & -0.015 & $-0.023^{\star \star}$ & -0.014 & $-0.021^{\star \star}$ & -0.017 & -0.015 & $-0.0086^{* *}$ & $-0.0064^{\star \star}$ & $-0.0087^{\star \star}$ & $-0.0078^{\star \star}$ \\
\hline & $(-1.46)$ & $(-2.04)$ & $(-1.29)$ & $(-1.99)$ & $(-1.62)$ & $(-1.51)$ & $(-2.51)$ & $(-1.99)$ & $(-2.51)$ & $(-2.36)$ \\
\hline \multirow[t]{2}{*}{ Cab seats social democrats } & & & $0.0066^{\star \star *}$ & & $0.0064^{\star \star *}$ & & & & & \\
\hline & & & $(2.68)$ & & $(2.75)$ & & & & & \\
\hline \multirow{2}{*}{$\begin{array}{l}\text { Cab seats three way } \\
\text { social democrats }\end{array}$} & & & & & & $0.0070^{* * *}$ & & $0.0034^{* * *}$ & & $0.0034^{\star * *}$ \\
\hline & & & & & & $(2.89)$ & & (3.73) & & (3.69) \\
\hline \multirow{2}{*}{$\begin{array}{l}\text { Welfare change* three } \\
\text { way social democrats }\end{array}$} & & & & & & & & & & $-0.00064^{\star \star}$ \\
\hline & & & & & & & & & & $(-2.38)$ \\
\hline \multirow[t]{2}{*}{ Feelings of safety } & -0.0060 & & & & & & & & & \\
\hline & $(-0.60)$ & & & & & & & & & \\
\hline
\end{tabular}


Table 3. (Continued)

\begin{tabular}{|c|c|c|c|c|c|c|c|c|c|c|}
\hline & (1) & (2) & (3) & (4) & (5) & (6) & (7) & (8) & (9) & (10) \\
\hline & ologit, full & ologit, full & ologit, full & $\begin{array}{l}\text { ologit, } \\
\text { parsim }\end{array}$ & $\begin{array}{l}\text { ologit, } \\
\text { parsim }\end{array}$ & $\begin{array}{l}\text { ologit, } \\
\text { parsim }\end{array}$ & ols (mod4) & ols (mod6) & $\begin{array}{c}\text { ols } \\
\text { (interac) }\end{array}$ & $\begin{array}{c}\text { ols } \\
\text { (interac) }\end{array}$ \\
\hline \multirow[t]{2}{*}{ Homicide rate } & & & $0.70^{\star}$ & & & & & & & \\
\hline & & & $(1.73)$ & & & & & & & \\
\hline \multirow[t]{2}{*}{ Net migration rate } & & $0.018^{\star \star \star}$ & & $0.017^{\star \star \star}$ & $0.018^{\star \star \star}$ & $0.015^{\star \star}$ & $0.0068^{\star \star \star}$ & $0.0052^{\star *}$ & $0.0063^{\star *}$ & $0.0055^{\star \star}$ \\
\hline & & $(2.77)$ & & $(2.75)$ & (2.93) & $(2.19)$ & $(2.79)$ & $(2.00)$ & (2.54) & $(2.16)$ \\
\hline \multirow[t]{2}{*}{ Fiscal balance } & -0.050 & -0.040 & -0.055 & -0.047 & & & -0.014 & & -0.014 & \\
\hline & $(-1.39)$ & $(-1.10)$ & $(-1.62)$ & $(-1.39)$ & & & $(-1.04)$ & & $(-1.07)$ & \\
\hline \multirow[t]{2}{*}{ Unemployment (preced. $6 \mathrm{~m}$ ) } & 0.014 & 0.033 & -0.019 & & & & & & & \\
\hline & $(0.27)$ & $(0.66)$ & $(-0.42)$ & & & & & & & \\
\hline \multirow[t]{2}{*}{ Constant (ols) } & & & & & & & $1.32^{\star \star \star *}$ & $0.58^{\star \star \star}$ & $1.32^{\star \star \star}$ & $0.59^{\star \star \star}$ \\
\hline & & & & & & & $(6.64)$ & $(6.58)$ & $(6.65)$ & $(6.72)$ \\
\hline \multirow[t]{2}{*}{ Constant (ologit, cut1) } & $-7.83^{* \star *}$ & $-7.45^{* \star *}$ & $-5.59^{* * *}$ & $-7.69^{\star \star *}$ & $-5.98^{* * *}$ & $-5.95^{\star \star *}$ & & & & \\
\hline & $(-7.19)$ & $(-9.68)$ & $(-9.73)$ & $(-11.18)$ & $(-13.45)$ & $(-13.36)$ & & & & \\
\hline \multirow[t]{2}{*}{ Constant (ologit, cut2) } & $-5.58^{\star * \star}$ & $-5.17^{\star \star \star}$ & $-3.30^{\star * *}$ & $-5.42^{\star \star \star}$ & $-3.71^{\star \star \star}$ & $-3.68^{\star \star *}$ & & & & \\
\hline & $(-5.40)$ & $(-7.15)$ & $(-6.55)$ & $(-9.03)$ & $(-12.99)$ & $(-12.75)$ & & & & \\
\hline \multirow[t]{2}{*}{ Constant (ologit, cut3) } & $-2.19^{\star \star}$ & $-1.70^{\star \star}$ & 0.14 & $-1.94^{\star \star \star}$ & -0.25 & -0.21 & & & & \\
\hline & $(-2.20)$ & $(-2.50)$ & $(0.30)$ & $(-3.58)$ & $(-1.31)$ & $(-1.10)$ & & & & \\
\hline \multirow[t]{2}{*}{ Constant (ologit, cut4) } & -0.28 & 0.24 & $2.05^{\star \star \star}$ & -0.0091 & $1.67^{\star \star *}$ & $1.71^{\star \star \star}$ & & & & \\
\hline & $(-0.28)$ & $(0.34)$ & $(4.59)$ & $(-0.02)$ & $(9.22)$ & (9.39) & & & & \\
\hline \multirow[t]{2}{*}{ Constant (ologit, cut5) } & 1.47 & $2.01^{\star \star \star}$ & $3.84^{\star \star \star}$ & $1.77^{\star \star \star}$ & $3.44^{\star \star \star}$ & $3.48^{\star \star \star}$ & & & & \\
\hline & $(1.40)$ & $(2.70)$ & $(7.47)$ & $(2.91)$ & $(10.88)$ & $(11.02)$ & & & & \\
\hline$n$ & 815 & 875 & 879 & 875 & 875 & 875 & 875 & 875 & 875 & 875 \\
\hline$R^{2}$ & 0.040 & 0.042 & 0.038 & 0.042 & 0.038 & 0.038 & 0.077 & 0.070 & 0.078 & 0.077 \\
\hline
\end{tabular}

Note: Country dummies included; ${ }^{*} p<0.1,{ }^{\star \star} p<0.05,{ }^{* \star *} p<0.01 ; z-(t-)$ statistics in parentheses. 

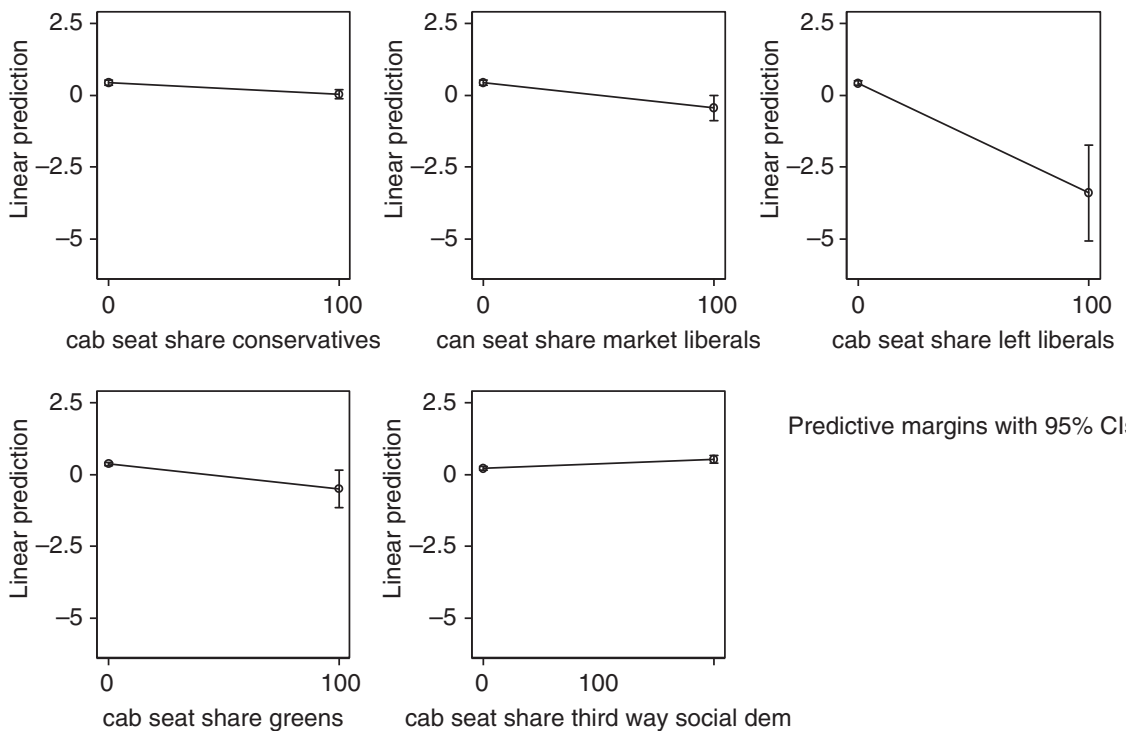

Figure 5. Predictive margins - penal policy and cabinet seat shares of parties. Note: Graphs based on model 7 (first four graphs) and model 8 (last graph) in Table 3.

our observation period: in fact, the presence of conservative party significantly reduces the repressiveness of penal legislation, although the size of the effect is very small (compared, e.g. to the coefficient for left-liberal parties). These results mesh well with case study evidence on Britain, according to which New Labour has strongly increased the toughness of law and order policies, whereas the successor Coalition government of Conservatives and Liberal Democrats slightly reduced repressiveness (Blackbourn 2018, 297; Pantazis and Pemberton 2012, 654). Similarly, one could also argue that social democrats can be more repressive in terms of penal legislation because they are more interventionist on the welfare side, or that conservatives often govern together with market liberals, which push them towards the more liberal pole. At any rate, the results are somewhat surprising and warrant further inspection. From the covariates, only the migration rate is significantly (and positively) related to penal harshness. Given the fact that both policies are often related (Fitzgerald et al. 2012), this is rather unsurprising. Again, as in many criminological studies, a direct association between homicide rates and penal policies could not be found. Moreover, a direct relationship between the change of welfare state legislation in the six months before a penal policy change is clearly not discernible (see coefficient for the first variable).

In order to see more clearly the strength of partisan influence, Figure 5 illustrates the marginal effects. The y-axes of all graphs are set to the same value to visualize the strength of the relationship between the cabinet seat share of the respective party and the size of penal policy change (ranging from -2 to 3 , with higher values indicating more repressive policies). From the figure transpires that left-liberal parties are the party family that most substantially pushing penal legislation toward a more liberal pole, followed by market liberals and greens (though less significant here, due 


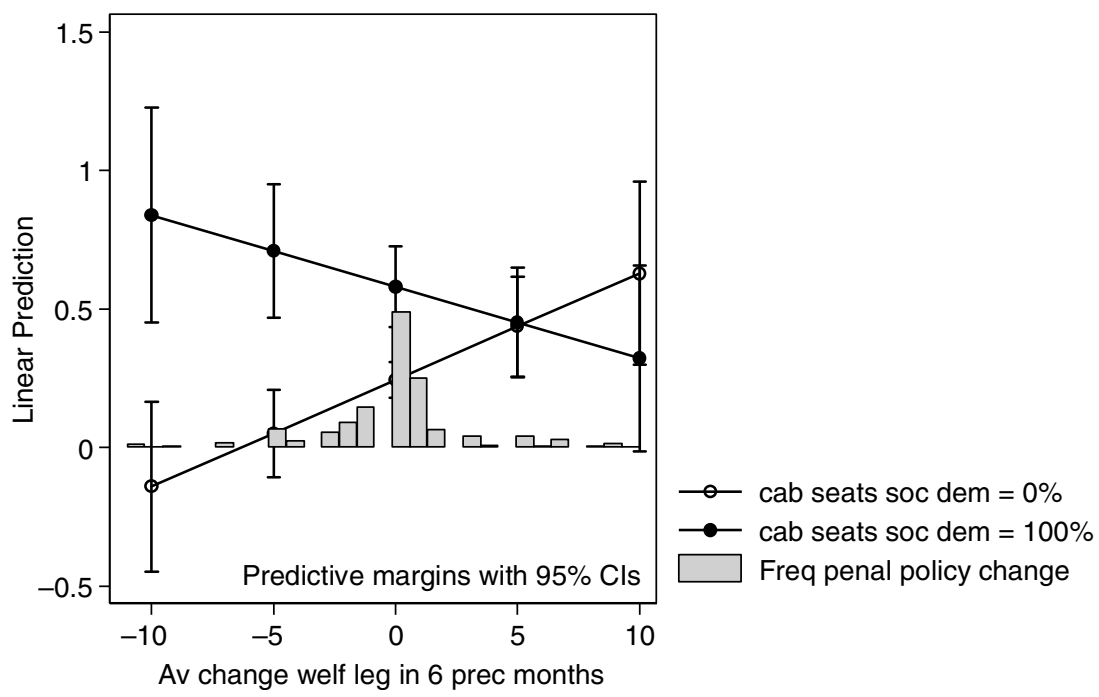

Figure 6. Third-way social democrats and the penal-welfare nexus. Note: Based on model 10 in Table 3.

to weak government participation for the greens). Hence, within the camp of liberal parties, it seems that left-liberals are most effective in pushing back tendencies to implement harsher penal policies. Moreover, the graphs also show that the somewhat surprising the negative coefficient of conservative cabinet seat shares and the positive coefficient of social democrats - which both are, however, much weaker in terms of effect size.

To sum up our findings on direct partisan effects of liberal parties ( $\mathrm{H} 1$ and $\mathrm{H} 2)$, we can conclude that while liberal and parties restrict the harshness of law and order legislation, they also push for welfare cutbacks. However, differentiating between left-liberals and market liberals adds some nuance to this finding. While left-liberals are more influential than their market-liberal sisters on penal policies, the opposite is true for welfare policies, where market liberals have a stronger effect.

To inspect the conditional penal-welfare nexus as put forward by $\mathrm{H} 3$ and $\mathrm{H} 4$, we have introduced interaction terms between the indicator of lagged average welfare change and the cabinet seat share of both conservatives and third-way social democrats in the parsimonious models 4 and 5 in Table 3 . The results of our analysis indicate that governments made up by third-way social democrats indeed seem to implement harsher penal policies in the months after a welfare cutback. ${ }^{12}$ For conservative parties, however, we do not find such an effect (see model 9 in Table 3). Figure 6 visualises how the effect of recent welfare cutbacks on penal legislation is conditioned by social democratic government participation by

\footnotetext{
${ }^{12}$ The same is true if we take the average value for 12 months instead of six. Please also note the slightly significant effect for green parties (on the $90 \%$ level), which is, however, linked to the social democrats, as both parties have frequently been together in coalition governments. For social democrats (third way and non-third way), the effect remains about the same but is no longer significant on the $95 \%$ level. Interactions with all other party families are nonsignificant (see the other models in Table A2 in the Appendix).
} 
calculating the marginal effects for two cases: a purely third-way social democratic government (such as New Labour, upper line with filled circles), and a government where third-way social democrats are absent (lower line with hollow circles). The interpretation is straightforward: our model predicts an increase in penal repressiveness if a third-way social democratic government has cut welfare in the six months before the penal policy change. The effect decreases as welfare legislation becomes more expansive. The opposite is true if no third-way social democrats are in office. This result together with the nonsignificant effect for conservative parties, for which no increase in penal harshness is estimated by our regression when the welfare state is cut, therefore lend support to $\mathrm{H} 4$ but reject $\mathrm{H} 3$. In sum, it, therefore, seems a penal-welfare nexus does not exist generally but it does exist under specific circumstances - namely if social democratic governments have set out to cut the welfare state. ${ }^{13}$ The interesting dissimilarity between the two main European party families might be related to different time horizons in their electoral motivation for linking the policy sectors in the first place - and our measurement. The necessity for conservative parties to assure middle- and upper-class constituents of the state's potency via penal policy might only arise as a long-term effect of welfare state retrenchment (Wacquant 2009b). Our measurement based on actual reforms catches much better a more direct penal-welfare nexus, of course. In this regard, the electoral strategy of third-way social democrats - to compensate for fiscally necessary welfare cuts with more intervention via the penal state - can manifest interaction effects over a shorter time horizon.

\section{Discussion and conclusion}

This study aimed to critically explore the penal-welfare nexus. Based on the idea of partisan effects, we argued that rather than a direct link between welfare and penal policy, the partisan composition of governments explains both the direction of penal and welfare policy individually, and whether welfare state changes are indeed followed by changes of penal policies. Adding to the literature on penal and welfare policies, we tested our expectations on a newly collected dataset which is based on manually coded measures of penal and welfare legislation.

Our article made two main contributions to the debate on the penal-welfare nexus. First, we argued that the standard approach to the analysis of partisan influence, opposing parties from the left and from the right, is inappropriate in the case of penal policies, because the programmatic position of liberal parties, who have repeatedly participated in governments, cuts across the standard left-right axis by pushing for economically right wing but culturally liberal penal policies. This theoretical claim was supported by our regression analysis on both penal and welfare policies: we found, indeed, substantial and significant evidence that higher cabinet seat shares of liberal and green parties, and left-liberals in particular, are associated with a less punitive penal policy output (H1). Similarly, our regression models show a strong and significant relationship between the presence of

\footnotetext{
${ }^{13}$ To assess the robustness of the results, we have run jackknifed and bootstrapped versions of the main models. The coefficients and significance of our main variables of interest were not affected.
} 
conservative- and market-liberal parties in government and cutbacks in welfare policy (H2).

Second, on the question of the nexus between penal and welfare legislation, i.e. the question whether harsher penal policies follow after welfare state retrenchment, we have theorised that again, partisan politics should matter. Our argument here relates to both the literature on the conservatives toughening up welfare and penal legislation and to the literature on third-way social democracy which maintains that a direct link between more repressive penal policies in connection with welfare cutbacks is most probable if social democratic parties govern. The empirical evidence generated based on our data is mixed. While the regression estimations do not confirm a relationship between welfare cutbacks and penal repression in the case of conservative governments (H3), we indeed find evidence for a penal-welfare nexus in legislation if third-way social democratic parties are strongly present in government $(\mathrm{H} 4)$.

These findings add to the works by Sutton $(2000,2004,2010,2013)$ and Wacquant (Wacquant 2001, 2009b) by looking beyond the well-studied US case and the most disadvantaged social strata of society, and by introducing a more fine-grained measure of partisanship than in the Suttons' analyses (Sutton 2004) building on a more complex theory of party competition on welfare and law and order issues. Finally, by presenting new hand-coded data on legislation, we are able to move beyond studies of imprisonment rates that are plagued by the very rough measure of policies via an outcome measure that is rather distant from the actual policy-making process.

Admittedly, as our analysis is based on a small sample of four countries, further investigations of possible cross-policy compensation effects between welfare and penal policy on a broader sample of nations are badly needed. Indeed, our findings on the social democratic influence on the penal-welfare nexus may well be influenced by the fact that the cases of Britain, Denmark and Germany are prominent cases of third-way governments. Nevertheless, as the third way has also affected other social democratic parties in Europe (Merkel et al. 2008), similar patterns may also be visible in other nation-states during a similar period of time.

Supplementary material. To view supplementary material for this article, please visit https://doi.org/10. 1017/S0143814X20000161

Data Availability Statement. Replication materials are available in the Journal of Public Policy Dataverse at https://doi.org/10.7910/DVN/H1S6B6.

Acknowledgement. Preliminary versions of this article have been presented at workshops in Barcelona, Darmstadt and Columbus $(\mathrm{OH})$, where we profited greatly from the comments by discussants and audiences. We would like to thank all coders in the associated projects and especially Lukas Øeby Feldbæk Nielsen of Aarhus University for their research assistance.

Funding statement. This work is partly based on two research projects funded by the German Research Foundation (DFG, grant: WE 4775/2-1) and the Danish Council of Independent Research (grant 4003-00013).

\section{References}

Adams JF, Merrill S and Grofman B (2005) A Unified Theory of Party Competition: A Cross-National Analysis Integrating Spatial and Behavioral Factors. Cambridge: Cambridge University Press. 
Allan JP and Scruggs L (2004) Political Partisanship and Welfare State Reform in Advanced Industrial Societies. American Journal of Political Science, 48(3): 496-512.

Arndt C (2013) The Electoral Consequences of Third Way Welfare State Reforms. Amsterdam: Amsterdam University Press.

Bakker R, de Vries C, Edwards E, Hooghe L, Jolly S, Marks G, Polk J, Rovny J, Steenbergen M and Vachudova M (2012) Measuring Party Positions in Europe: The Chapel Hill Expert Survey Trend File, 1999-2010. Unpublished manuscript.

Beckett K and Bruce W (2001) Governing Social Marginality. Welfare, Incarceration, and the Transformation of State Policy, Punishment \& Society, 3(1): 43-59.

Béland D (2009) Ideas, Institutions, and Policy Change. Journal of European Public Policy, 16(5): 701-718.

Bell DS (2003) French Socialists: Refusing the "Third Way". Journal of Policy History, 15(1): 46-64.

Benoit K and Laver M (2006) Party Policy in Modern Democracies. London: Routledge.

Blackbourn J (2018) Accountability, Counter-Terrorism and Civil Liberties. King's Law Journal, 29(2): 297-323.

Blair T (2010) A Journey. London: Hutchinson.

Bourgoin N (2015) La République Contre Les Libertés. Paris: L'Harmattan.

Bradley D, Huber E, Moller S, Nielsen F and Stephens JD (2003) Distribution and Redistribution in Postindustrial Democracies. World Politics, 55: 193-228.

Brouard S, Wilkerson J, Baumgartner FR, Timmermans A, Bevan S, Breeman G, Breunig C, Chaqués L, Green-Pedersen C, Jennings W, John P, Jones BD and Lowery D (2009) Comparer les productions législatives: enjeux et méthodes. Revue internationale de politique comparée, 16(3): 381-404.

Budde E, Heichel S, Hurka S and Knill C (2018) Partisan Effects in Morality Policy Making. European Journal of Political Research, 57(2): 427-449.

Campbell JL (2010) Neoliberalism's Penal and Debtor States. Theoretical Criminology, 14(1): 59-73.

Castles F and McKinlay RD (1979) Does Politics Matter: An Analysis of the Public Welfare Commitment in Advanced Democatic States. European Journal of Political Research, 7(2): 169-186.

Cavadino M and Dignan J (2006) Penal Systems - A Comparative Approach. London: Sage.

Centeno MA and Cohen JN (2012) The Arc of Neoliberalism. Annual Review of Sociology, 38(1): 317-340.

Clasen J (2002) Unemployment and Unemployment Policy in Britain: Increasing Employability and Re-defining Citizenship. In Goul-Andersen JG, Clasen J, Halversen K and van Oorschot W (eds.), Europe's New State Of Welfare: Unemployment, Employment Policies And Citizenship. Bristol: Policy Press, 59-74.

Clasen J (2005) Reforming European Welfare States: Germany and The United Kingdom Compared. Oxford: Oxford University Press.

Clift B (2000) Is There a French 'Third Way'? New Political Economy, 5(1): 135.

Crouch C (2013) The Strange Non-Death of Neo-Liberalism. Cambridge: Polity.

Downes D and Hansen K (2006) Welfare and Punishment in Comparative Perspective. In Armstrong S and McAra L (eds.), Perspectives on Punishment. Oxford: Oxford University Press, 101-118.

Drinkwater S and Jennings C (2017) Expressive Voting and Two-Dimensional Political Competition: An Application to Law and Order Policy by New Labour in the UK. Constitutional Political Economy, 28(1): 79-96.

Elbaum M (2011) Économie Politique De La Protection Sociale. Paris: Presses Universitaires de France.

Esping-Andersen G (1990) The Three Worlds of Welfare Capitalism. Cambridge: Polity Press.

Estrada F (2004) The Transformation of the Politics of Crime in High Crime Societies. European Journal of Criminology, 1(4): 419-443.

Ferrera M (2013) Welfare-State Transformations: From Neo-Liberalism to Liberal Neo-Welfarism? In Thatcher $\mathrm{M}$ and Schmidt VA (eds.), Resilient Liberalism in Europe's Political Economy. Cambridge: Cambridge University Press, 77-111.

Fitzgerald J, Curtis KA and Corliss CL (2012) Anxious Publics: Worries about Crime and Immigration. Comparative Political Studies, 45(4): 477-506.

Garland D (2001) The Culture of Control: Crime and Social Order in Contemporary Society. Oxford: Oxford University Press.

Giddens A (2000) The Third Way and Its Critics. Cambridge: Polity Press.

Goertz G and Mahoney J (2012) A Tale of Two Cultures. Qualitative and Quantitative Research in The Social Sciences. Princeton: Princeton University Press. 
Green-Pedersen C (2019) The Reshaping of West European Party Politics: Agenda-Setting and Party Competition in Comparative Perspective. Oxford: Oxford University Press.

Hall P and Soskice D (ed.) (2001), Varieties of Capitalism. Oxford: Oxford University Press.

Häusermann S, Picot G and Geering D (2013) Rethinking Party Politics and the Welfare State. British Journal of Political Science, 43(1): 221-240.

Hibbs D (1977) Political Parties and Macroeconomic Policy. American Political Science Review, 71(4): 1467-1487.

Huber E and Stephens JD (2001) Development and Crisis of the Welfare State. Chicago/London: Chicago University Press.

Huo J (ed.) (2009) Third Way Reforms. Social Democracy after the Golden Age. New York: Cambridge University Press.

IAB (2017) Institut für Arbeitsmarkt und Berufsforschung: Gesamtfiskalische Kosten der Arbeitslosigkeit im Jahr 2015 in Deutschland, http://doku.iab.de/arbeitsmarktdaten/Kosten_ALO_2015.pdf (accessed 13 February 2020).

Inglehart RF (2008) Changing Values among Western Publics from 1970 to 2006. West European Politics, 31(1-2): 130-146.

Jensen C, Arndt C, Lee S and Wenzelburger G (2018) Policy Instruments and Welfare State Reform. Journal of European Social Policy, 28(2): 161-176.

Jensen C and Wenzelburger G (2020a) New Evidence on the Effect of Partisanship on the Welfare State. In Careja R, Emmenegger P and Giger N (eds.), The European Social Model Under Pressure: Liber Amicorum in Honour of Klaus Armingeon. Wiesbaden: Springer Fachmedien Wiesbaden, 123-137.

Jensen C and Wenzelburger G (2020b) Reforming the Welfare State. London: Routledge.

JM NRW (2018) Ministerium der Justiz des Landes Nordrhein-Westfalen: Gesamtkosten des Vollzuges, https://www.justiz.nrw.de/Gerichte_Behoerden/zahlen_fakten/statistiken/justizvollzug/kosten.pdf (accessed 13 February 2020).

Jones BD and Baumgartner FR (2005) The Politics of Attention: How Government Prioritizes Problems. Chicago: University of Chicago Press.

King G, Keohane RO and Verba S (1994) Designing Social Inquiry. Princeton: Princeton University Press.

Kitschelt H and Hellemans S (1990) The Left-Right Semantics and the New Politics Cleavage. Comparative Political Studies, 23(2): 210-238.

Kitschelt $\mathbf{H}$ and Rehm P (2016) Party Alignments: Change and Continuity. In Beramendi P, Häusermann S, Kitschelt $\mathrm{H}$ and Kriesi $\mathrm{H}$ (eds.), The Politics of Advanced Capitalism. Cambridge: Cambridge University Press, 179-201.

Kittel B and Obinger H (2003) Political Parties, Institutions, and the Dynamics of Social Expenditure in Times of Austerity. Journal of European Public Policy, 10(1): 20-45.

Knill C and Tosun J (2012) Public Policy. A New Introduction. London: Palgrave Macmillan.

Korpi W (1983) The Democratic Class Struggle. London: Routledge.

Korpi W and Palme J (2003) New Politics and Class Politics in the Context of Austerity and Globalization: Welfare State Regress in 18 Countries, 1975-1995. American Political Science Review, 97(3): 425-446.

Kriesi H, Grande E, Lachat R, Dolezal M, Bonschier S and Frey T (2008) West European Politics in the Age of Globalization. Cambridge: Cambridge University Press.

Lacey N (2008) The Prisoners' Dilemma. Cambridge: Cambridge University Press.

Lacey N, Soskice D and Hope D (2018) Understanding the Determinants of Penal Policy: Crime, Culture, and Comparative Political Economy. Annual Review of Criminology, 1(1): 195-217.

Lappi-Seppälä T (2008) Trust, Welfare, and Political Culture: Explaining Differences in National Penal Policies. Crime and Justice, 37(1): 313-387.

Lee S, Jensen C, Arndt C and Wenzelburger G (2020) Risky Business? Welfare State Reforms and Government Support in Britain and Denmark. British Journal of Political Science, 50(1): 165-184.

Lijphart A (2012) Patterns of Democracy: Government Forms and Performance in Thirty-Six Countries. New Haven: Yale University Press.

Lohrenz C (2014) Hollande Chooses 'Third Way' on Economy. Deutsche Welle.

Mayer M (2010) Punishing the Poor-A debate. Theoretical Criminology, 14(1): 93-103.

Medina-Ariza J (2006) Politics of Crime in Spain, 1978-2004. Punishment \& Society, 8(2): 183-201.

Melossi D (1987) Political Business Cycles and Imprisonment Rates in Italy: Report on a Work in Progress. Review of Black Political Economy, 16(1-2): 211-218. 
Merkel W, Petring A, Henkes C and Egle C (2008) Social Democracy in Power. The Capacity to Reform. Milton Park: Routledge.

Mucchielli L (2010) Vers une criminologie d'État en France ? Institutions, acteurs et doctrines d'une nouvelle science policière. Politix, 89(1): 195-214.

Newburn T (2007) "Tough on Crime": Penal Policy in England and Wales. Crime and Justice, 36(1): 425-470.

Newburn T and Reiner R (2007) Crime and Penal Policy. In Seldon A (ed.), Blair's Britain. Cambridge: Cambridge University Press, 318-340.

Norris PA (2009) Families of Nations, Victimisation and Attitudes Towards Criminal Justice. International Review of Victimology, 16(3): 229-255.

Palier B (2005) Gouverner La Sécurité Sociale. Paris: Presses Universitaires de France.

Pantazis C and Pemberton S (2012) Reconfiguring Security and Liberty: Political Discourses and Public Opinion in the New Century. British Journal of Criminology, 52(3): 651-667.

Pierson P (1994) Dismantling the Welfare State? Reagan, Thatcher, and the Politics of Retrenchment. Cambrigde: Cambridge University Press.

Pierson P (2001) Coping with Permanent Austerity. Welfare State Restructuring in Affluent Democracies. In Pierson P (ed.), The New Politics of the Welfare State. Oxford/New York: Oxford University Press, $410-456$.

Piven FF (2010) A Response to Wacquant. Theoretical Criminology, 14(1): 111-116.

Potrafke N (2017) Partisan Politics: The Empirical Evidence from OECD Panel Studies. Journal of Comparative Economics, 45(4): 712-750.

Roché S (2012) Les politiques de sécurité intérieure. In de Maillard J and Surel Y (eds.), Les Politiques Publiques Sous Sarkozy. Paris: Presses de Sciences Po, 237-258.

Rodríguez-Menés J and López-Riba J (2019) The Impact of the 2008 Economic Crisis on Imprisonment in Europe. European Journal of Criminology, Early View: 1-32.

Rusche G and Kirchheimer O (1968) Punishment and Social Structure. New York: Russell \& Russell.

Sartori G (1976) Parties and Party Systems. Cambridge: Cambridge University Press.

Savage L (2019) The Politics of Social Spending After the Great Recession: The Return of Partisan Policy Making. Governance, 32(1): 123-141.

Schmidt MG (1996) When Parties Matter: A Review of the Possibilities and Limits of Partisan Influence on Public Policy. European Journal of Political Research, 30(2): 155-183.

Schmitt C (2016) Panel Data Analysis and Partisan Variables: How Periodization does Influence Partisan Effects. Journal of European Public Policy, 23(10): 1442-1459.

Simmons BA, Dobbin F and Garrett G (2006) Introduction: The International Diffusion of Liberalism. International Organization, 60(4): 781-810.

Simon J (2007) Governing Through Crime. Oxford: Oxford University Press.

Smith G (1988) Between Left and Right: The Ambivalence of European Liberalism. In Kirchner EJ (ed.), Liberal Parties in Western Europe. Cambridge: Cambridge University Press, 16-28.

Squires P and Lea J (eds.) (2012), Criminalisation and Advanced Marginality. Critically Exploring the Work of Loïc Wacquant. Bristol: Policy Press at the University of Bristol.

Stenson K and Edwards A (2001) Rethinking Crime Control in Advanced Liberal Government: The 'Third' Way and the Return to the Local. In Stenson K and Sullivan RR (eds.), Crime, Risk and Justice. The Politics of Crime Control in Liberal Democracies. Portland: Willan Publishing, 68-86.

Stokes SC (1999) Political Parties and Democracy. Annual Review of Political Science, 2(1): 243-267.

Sutton JR (2000) Imprisonment and Social Classification in Five Common-Law Democracies, 1955-1985. American Journal of Sociology, 106(2): 350-386.

Sutton JR (2004) The Political Economy of Imprisonment in Affluent Western Democracies, 1960-1990. American Sociological Review, 69(2): 170-189.

Sutton JR (2010) Imprisonment and Opportunity Structures: A Bayesian Hierarchical Analysis. European Sociological Review, 28(1): 12-27.

Sutton JR (2013) The Transformation of Prison Regimes in Late Capitalist Societies. American Journal of Sociology, 119(3): 715-746.

Svallfors S (2012) Welfare States and Welfare Attitudes. In Svallfors S (ed.), Contested Welfare States. Stanford: Stanford University Press, 1-24. 
Taylor I, Walton P and Young J (1975) Critical Criminology in Britain: Review and Prospects. In Taylor I, Walton P and Young J (eds.), Critical Criminology. London/Boston: Routledge \& Kegan Paul, 6-62.

Tham H (2001) Law and Order as a Leftist Project?: The Case of Sweden. Punishment \& Society, 3(3): 409-426.

Thelen K (2014) Varieties of Liberalization and the New Politics of Social Solidarity. Cambridge: Cambridge University Press.

Tonry M (2007) Determinants of Penal Policies. In Tonry M (ed.), Crime, Punishment, and Politics in Comparative Perspective. Chicago/London: University of Chicago Press, 1-48.

Tonry M (2015) Is Cross-National and Comparative Research on the Criminal Justice System Useful? European Journal of Criminology, 12(4): 505-516.

Van Kersbergen K and Manow P (eds.) (2009) Religion, Class Coalitions, and Welfare States. Cambridge: Cambridge University Press.

von Beyme K (1982) Parteien in Westlichen Demokratien. München: Piper.

Wacquant L (2001) The Penalisation of Poverty and the rise of Neo-Liberalism. European Journal on Criminal Policy and Research, 9(4): 401-412.

Wacquant L (2009a) Prisons of Poverty. Minneapolis: University of Minnesota Press.

Wacquant L (2009b) Punishing the Poor. The Neoliberal Government of Social Insecurity. Durham/London: Duke University Press.

Wenzelburger G (2015) Parties, Institutions and the Politics of Law and Order. British Journal of Political Science, 45(3): 663-687.

Wenzelburger G (2018) Political Economy or Political Systems? How Welfare Capitalism and Political Systems Affect Law and Order Policies in Twenty Western Industrialised Nations. Social Policy and Society, 17(2): 209-226.

Wenzelburger G (2020) The Partisan Politics of Law and Order. Oxford: Oxford University Press.

Wenzelburger G, Arndt C and Jensen C (2018) Sozialstaatliche Kürzungspolitik in Deutschland: Nur eine Mär? Eine quantitative Gesetzgebungsanalyse 1974-2014, Politische Vierteljahresschrift.

Wenzelburger G and Staff H (2016) German Exceptionalism? An Empirical Analysis of 20 Years of Law and Order Legislation. Politics \& Policy, 44(2): 319-350.

Wenzelburger G and Staff $\mathbf{H}$ (2017) The 'Third Way' and the Politics of Law and Order: Explaining Differences in Law and Order Policies Between Blair's New Labour and Schröder's SPD. European Journal of Political Research, 56(3): 553-577.

Zohlnhöfer R, Engler F and Dümig K (2017) The Retreat of the Interventionist State in Advanced Democracies. British Journal of Political Science, 48(2): 535-562.

Cite this article: Staff H and Wenzelburger G (2021). The partisan politics of the penal-welfare nexus: a quantitative analysis of party influence on the relationship between penal and welfare policies. Journal of Public Policy 41, 573-599. https://doi.org/10.1017/S0143814X20000161 